\title{
Can Capital Ratios be the Centre of Banking Regulation - A Case Study
}

\author{
Milena MARINOVA*
}

\section{Introduction}

Since the financial crisis started mid-2007, the poor economic conditions affected adversely numerous banks. The selected banks analyzed in this paper were affected more than their peers although their capital ratios were far above the regulatory minimum capital charges of eight percent.

\subsection{Objectives of this paper}

I elaborate a case study in order to question the usefulness and reasonability of the full regulatory reliance on capital ratios. This paper should be viewed as a contribution of mine to the analysis of the reasons for the numerous bank runs, and of the flaws and failures in the current financial regulation and treatment of securitizations.

I focus my analysis on capital ratios, so in the following sections I concentrate on the capital management and regulatory capital issues in selected banks. I analyze the several selected cases in order to show that capital ratios alone cannot be a measure for the insolvency of an individual financial institution.

In particular, the common pattern of the selected banks is that they largely invested in mortgage origination and securitization, which in turn increased their leveraged exposures.

The high leverage and parallelly the drain of credit risk out of the single banks' balance sheets are not captured by the current European regulatory capital requirements and cannot be captured by the regulatory capital ratios in their current form.

Milena Marinova, lic.oec.int. - Ernst\&Young AG, Mergenthalerallee 3-5, 65760 Eschborn, Germany,; <milena.marinova@de.ey.com>. 
For that reason neither disclosure of the financial ratios, including capital ratios, nor disclosure of other internal and external risk management techniques provided a signal of the coming runs until they factually came.

All the selected banks in my analysis were largely exposed to securitization and resecuritization transactions, among others of U.S. sub-prime mortgages.

It is nowadays obvious that the "current" banking regulation Basel II possesses numerous flaws, in particular within the securitization framework. As regulators slowly perceived the earnest of the current situation in the financial markets enhancements to the Basel II capital requirements regarding securitizations were proposed. Comments on the latest proposals are out of the scope of this paper.

\section{Case Studies}

\subsection{The IKB case}

IKB Deutsche Industriebank is a specialist bank for corporate lending in Germany and Europe. Its target groups are small and medium-sized enterprises as well as multinational enterprises and project partners.

As such, IKB is subject to the regulations applicable to German banks and bank groups ${ }^{1}$. Risk-weighted assets must be backed with at least $8 \%$ equity (capital or solvency ratio). Risk-weighted assets that are backed with core capital are subject to a minimum ratio of $4 \%$ (core capital ratio).

IKB applied the transitional regulation for implementing Basel $\mathrm{II}^{2}$ and continued to calculate regulatory indicators in accordance with principle I (Grundsatz I) until 31 December 2007. From 1st January 2008 the Basel II regulations were applied (SolvV). Risk-weighted assets were determined according to the Standardized Approach.

1 In particular, these are paragraphs 10 and 10a of the KWG (Kreditwesengesetz) and Principle I (Grundsatz I, the German Capital Requirements Directive according to Basel I), which state that sufficient regulatory capital must be held.

2 Paragraphs 339 (9) of the German Solvability Ordinance (Solvabilitätsverordnung) 
Marinova, M.: Can Capital Ratios be the Centre of Banking Regulation - A Case Study.

The graph below shows the capital ratios (capital ratio and the core capital ratio) of IKB in the past ten years.

Fig. 1: Capital ratios in percent, IKB - 1998 to 2008

Capital ratios in percent

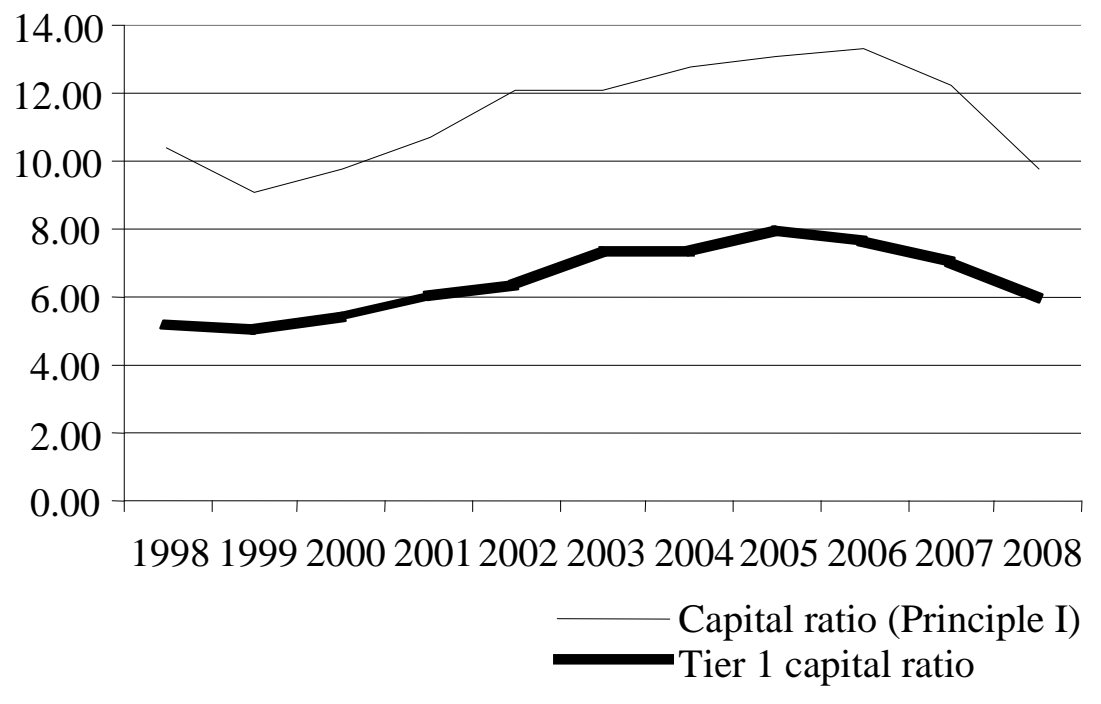

Source: own presentations based on IKB (2007a, 2007b, 2008, 2009)

As can be seen, the capital ratios have always been far above the minimum capital requirements according to Basel. This fact however did not help IKB to escape the sub-prime crisis.

IKB was completely destroyed by its investments in the U.S. subprime mortgage market. In fact, IKB had invested in groups of assets to U.S. sub-prime real estate loans via its off balance sheet vehicles Rhineland Funding and Rhinebridge plc. In August 2007 the bank ousted its chief financial officer (CFO) as a response to its financial collapse.

As a response to the collapse of IKB, Kreditanstalt für Wiederaufbau (KfW) - a strong German state-owned institute, being the controlling shareholder in IKB with 38 percent, poured $€ 8.1$ billion into the off balance sheet vehicles Rhineland Funding and $€ 80$ million in Rhinebridge plc in order to save IKB. 
According to IKB, in the financial year 2007/08 the main purpose of capital management was to ensure the minimum regulatory ratios that were required as a result of the financial crisis.

The main problems of IKB were its securitization ${ }^{3}$ investments in the U.S. mortgage market. It can be seen in tables below that about fifty percent of IKB's portfolio investments was invested in securitization notes (ABS), with the greatest part of it (more than forty percent) in turn invested in sub-prime mortgages.

Tab. 1: Asset structure of IKB's portfolio investments, 30 June 2008

\begin{tabular}{|l|c|c|c|c|}
\hline \multirow{2}{*}{ Underlying portfolios } & \multicolumn{3}{|c|}{$\mathbf{3 0}^{\text {th }}$ June, 2008 } & \multicolumn{3}{|c|}{$\mathbf{3 1}^{\text {st }}$ March, 2008 } \\
\cline { 2 - 5 } & $\begin{array}{c}\text { Nominal } \\
\text { amount in } € \\
\text { billion }\end{array}$ & $\begin{array}{c}\text { in } \\
\%\end{array}$ & $\begin{array}{c}\text { Nominal } \\
\text { amount in } € \\
\text { billion }\end{array}$ & $\begin{array}{c}\text { in } \\
\%\end{array}$ \\
\hline Corporates & 2.5 & 50 & 2.7 & 46 \\
\hline ABS & 2.2 & 43 & 2.3 & 41 \\
\hline therof with sub-prime content & 1.7 & 34 & 1.8 & 32 \\
\hline ABS / Corporates mixed & 0.4 & 7 & 0.7 & 13 \\
\hline therof with sub-prime content & 0.2 & 4 & 0.2 & 4 \\
\hline Total & 5.1 & 100 & 5.7 & 100 \\
\hline
\end{tabular}

Source: IKB, interim report June, 2008

According to IKB's Annual Report 2008 the following regulatory and risk management treatment of securitization and in particularly structured finance notes (collateralized debt obligations CDOs, also known as resecuritization exposures) applied and was presented under the category "Spread risk":

3 Securitization is a process in which assets, receivables or financial instruments are being pooled, and sold as "collateralized" assets to investors. These collateralized assets are "backed" by the cash flow or value of the originally underlying assets. Thus securitization is a method of transferring risk from one party, the Originator, to Investors through capital market transactions. The risks of the originally underlying assets are transferred to Investors by the cash sale of debt instruments (bonds), known as Asset Backed Securities (ABS), whose cash flows and performance are completely dependent on the underlying portfolio of assets sold. 
Marinova, M.: Can Capital Ratios be the Centre of Banking Regulation - A Case Study.

"Spread risk results from changes in the default and liquidity premiums over the risk-free interest rate that is priced into securities and derivatives. Spread risk is particularly relevant to the Bank's portfolio investments (see table above). At the end of the first quarter of the current financial year, CDOs of Corporates and CDOs of CDOs were included in VaR calculations for the first time using historical simulation in order to allow an integrated perspective for the calculation of the overall risk-bearing capacity."

Die inadequateness of $\mathrm{VaR}$ as a measure for the risks hidden in securitization and resecuritization products is nowadays commonly acknowledged. The VaR measurement citation in these lines just underpins the inadequateness and inappropriateness of the current risk measurement concept of the already hit IKB. It is furthermore surprising not only that this concept was End of 2008 still applied with respect to the above mentioned resecuritization exposures, it is more astonishing that the annual report was accepted and sighed by the yearend auditor of the Bank although the inadequateness of $\mathrm{VaR}$ for resecuritizations is nowadays commonly acknowledged, at latest after the crisis.

\section{Resuming remark}

The obvious insights from the annual reports and the data presented above are:

- Despite regulatory capital ratios which were over long period far above the regulatory required minimum, IKB was not able to absorb the significant losses resulting from the sub-prime crisis spread from the U.S. world-wide;

- The large securitization (asset backed securities ABS, to the largest part consisting of sub-prime loans, see table above) and resecuritization exposures (ABS $\mathrm{CDOs}^{4}, \mathrm{CDO}$ of $\mathrm{CDO}^{5}$ also to the largest part consisting of sub-prime loans) did not draw the appropriate attention of the Bank's management prior to the financial turmoil;

4 Collateralized debt obligations backed by asset backed securities ABS CDO.

5 Collateralized debt obligations backed by collateralized debt obligations CDO of $\mathrm{CDO}, \mathrm{CDO}$ square. 
- Late after the financial turmoil, inappropriate risk measurement (VaR citation above from the Annual Report 2008/2009) was still applied and disclosed;

- Only due to the strong government support (bailout) IKB escaped its insolvency.

To resume, first the insufficiency of capital ratios as an adequate measure of single bank's s stability is obvious. Second, one has to admit on the basis of the above presented IKB disclosures that the recent financial crisis was not only a "Securitization Crisis", but also a "Crisis of Professional Incompetence".

\subsection{Sachsen LB}

Landesbank Sachsen Girozentrale (Sachsen LB) is a German state lender which was largely exposed to US sub-prime mortgage debt.

Although its capital situation was stabile and the regulatory capital ratios far above the required minimum (table below), Sachsen LB became one of Europe's biggest victims of the credit crisis. The capital situation of Sachsen LB at the beginning of the financial turmoil was as follows (see Fig. 2). According to its Annual Report 2005, Sachsen LB Europe, an affiliate on Sachsen LB in Dublin, Ireland, was a leading asset backed securities investor in Europe. At first, the Dublin affiliate Sachsen LB Europe focused on risk-averse low-return investments, such as European corporate and government bonds. However, this strategy had to be changed in order to improve the competitiveness and return prospects of Sachsen LB, as explained in the following paragraphs.

Sachsen LB, analogous the rest of the Landesbanken in Germany, was concerned about the competitiveness of its businesses after the expiration of the state guarantees for Landesbanken in July $2005^{6}$. The justified concern of the Landesbanken was that with the expiration of

6 The state guarantees until July 2005 (die Gewährträgerhaftung) led the following advantage for Landesbanken. If a publicly owned company had debts higher than its assets, the Landesbanken as its creditors were allowed to turn directly to the government for emergency funding. Thus, the state guarantees helped Landesbanken to be assigned first class credit ratings (AAA) and refinance their operations cheaper than its peers. However, the European Commission abolished the state guarantees with a decision from 2001 coming into force by July 2005 in order to remove competitive advantages for Landesbanken. 
Marinova, M.: Can Capital Ratios be the Centre of Banking Regulation - A Case Study.

the government backing the price of borrowing would increase, making capital markets profits difficult to achieve, especially for Landesbanken as opposed to the large internationally active commercial banks in Germany, such as Deutsche, Dresdner, and Commerzbank etc.

Fig. 2: Capital ratios in percent, Sachsen LB - 2002 to 2007

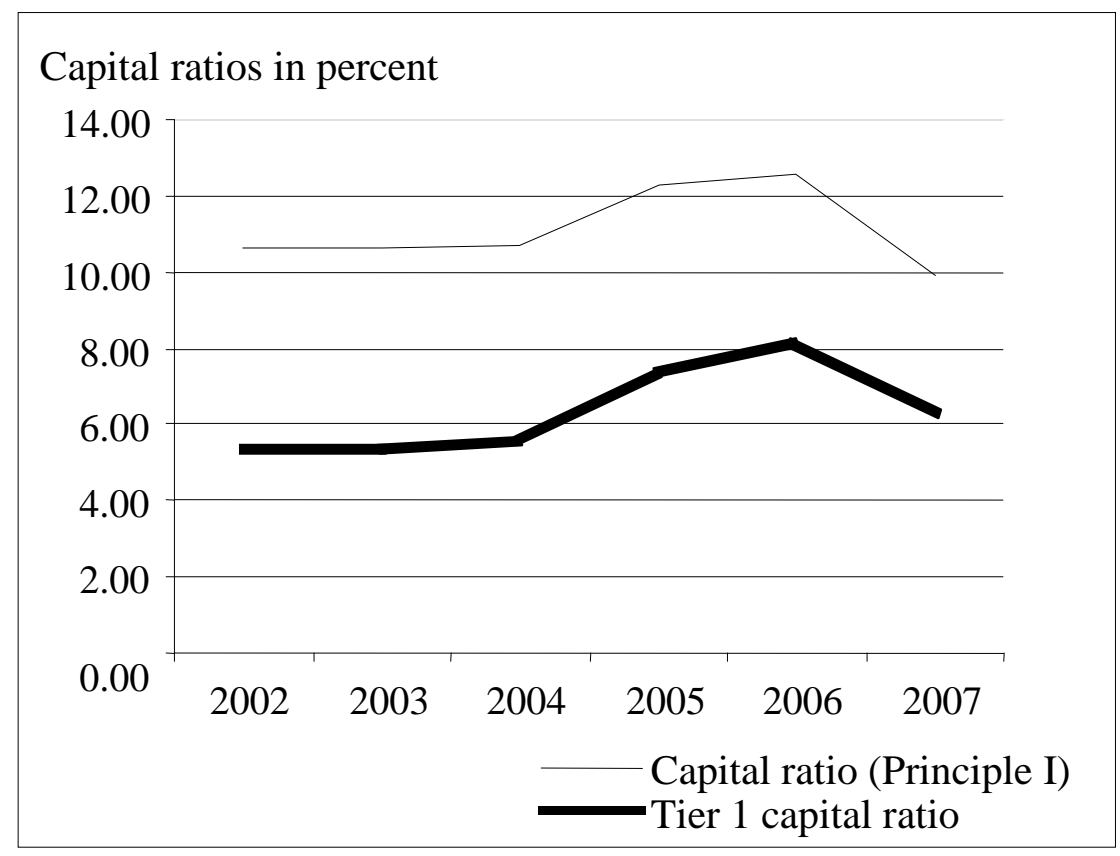

Source: own presentations based on Landesbank Sachsen LB (2006, 2007, 2008), Landesbank Sachsen Girozentrale (2005)

In order to improve the bank's competitiveness, Sachsen LB's management ${ }^{7}$ pushed the expansion of its Dublin affiliate Sachsen LB Europe into capital market activities, in particular in investing in various types of assets backed securities, including collateralized mortgages.

According to the bank's annual report, Sachsen LB Europe managed by 2002 about 11 billion euros of synthetic assets, which was at that time 77 times higher than its shareholder equity. Furthermore, Sachsen LB's credit committee, composed of regional executives and politicians,

7 One board member objected to the expansion of Sachsen LB Europe and left the Bank at the end of 2001 as his proposal to invest in SMEs credit expansion was vetoed. 
voted to push up to Euro 43 billion by 2010 into capital markets via the off-balance sheet vehicle Ormond Quay.

The extreme high profits of Sachsen LB Europe caught the attention of BaFin - the banking supervisor in Germany, which mandated the auditing company KPMG to a special audit Sachsen LB Europe in 2004. KPMG found, "that Sachsen's administrative board was unaware of the level of investments made at the subsidiary or the potential losses they posed".

According to a press release of Sachsen LB (February 2007, just days before the U.S. sub-prime-mortgage turmoil started) Sachsen LB's Irish affiliate - Sachsen LB Europe - was one of Ireland's most profitable banks.

The German state (Sachsen) was forced to sell the troubled state lender. Sachsen LB was taken over by the German contemporary biggest regional state lender LBBW (Landesbank Baden Württemberg). Additionally, in order to save the run, Sachsen LB received an emergency 17.3 billion Euro line of credit from a group of regional savings banks in August 2007. In order to sell Sachsen LB to LBBW, the state Saxony provided guarantees of up to 2.8 billion euros to cover losses on a new fund, into which 16 billion euros of assets from Ormond Quay and Sachsen Funding were placed.

\section{Resuming remark}

The situation at Sachsen LB was almost identical with the one of IKB:

- Despite long period of regulatory capital ratios far above the regulatory required minimum, Sachsen LB was not able to absorb the sub-prime losses;

- The large securitization and resecuritization exposures did draw the attention of the Bank's management prior to the financial turmoil but this did not change the investment strategy of the bank;

- BaFin tried to intervene but for certain reasons this intervention did not end successfully. Thus the prevention of the Sachsen LB's run failed.

- Only due to the strong government support (bailout) Sachsen LB escaped its insolvency. 
Marinova, M.: Can Capital Ratios be the Centre of Banking Regulation - A Case Study.

\subsection{The Northern Rock case}

The U.K. mortgage lender Northern Rock was the first bank experiencing a run in the recent crisis. It happened despite the presented a "very positive medium term outlook for the Company" in Northern Rock's interim report (July 25, 2007). The effects of the U.S. sub-prime crisis on Northern Rock were so destroying that, despite a large emergency liquidity support from the Bank of England, Northern Rock had to be taken into public ownership in February 2008.

According to the Mid-Year Report 2007, on 29 June 2007 and with effect from that date Northern Rock received its FSA $^{8}$ approval for Basel II application. Northern Rock adopted the Internal Ratings Based (IRB) approach for retail exposures in residential and personal unsecured loans, the Foundation IRB approach for treasury portfolios and the Standardized approach for commercial loans.

Through the implementation of Basle II the risk weighted assets at 30 June 2007 fell from around $£ 33.9$ billion under Basle I to $£ 18.9$ billion under Basle II, a reduction of ca. $44 \%$.

According to Northern Rock "The introduction of Basle II, together with the planned disposal of capital inefficient assets results in an anticipated regulatory capital surplus over the next 3 to 4 years. This surplus will ........ permit capital repatriation of up to $£ 300$ to $£ 400$ million over this period. Such repatriation will follow the release of capital as a result of asset disposals and will ensure that available capital is sufficient to support existing rating agency credit ratings and maintain an appropriate mix of Tier 1 and Tier 2 capital." Further, in the "Outlook" of the interim report 2007 Northern Rock wrote: "We are the most cost efficient lender in our sector and we remain positive on our outlook for the medium term".

8 Financial Services Authority, the regulatory body in Great Britain.

9 The risk weighting for residential mortgages reduced to mid-teens $\%$, treasury assets to around half of Basle I requirements, also around mid teens \%, reflecting according to Northern Rock' Mid-Year Report 2007 - the low risk nature of these portfolios and personal unsecured loans to slightly below Basle I requirements. 
Fig. 3: Capital ratios Northern Rock

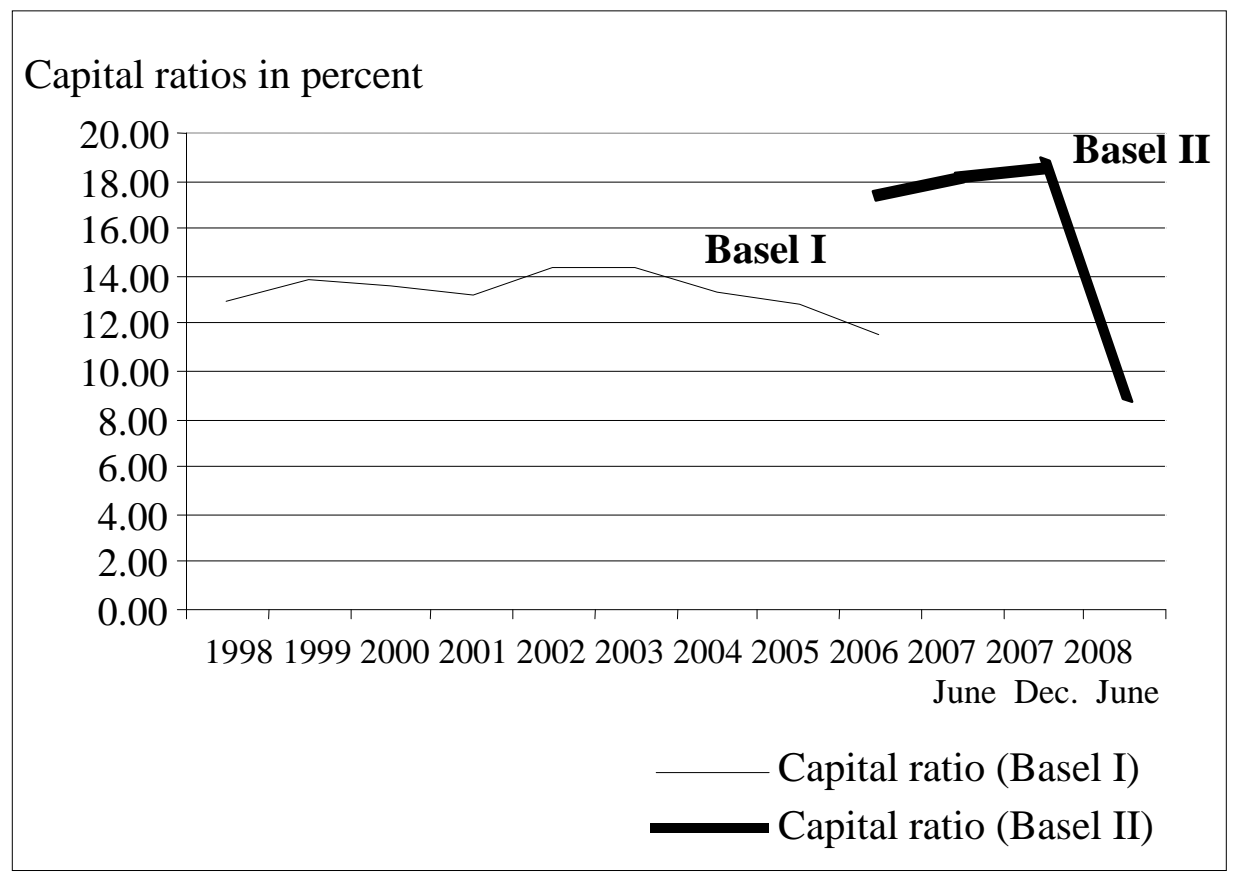

Source: own presentations based on Northern Rock 2007, 2009

Thus, Northern Rock not only complied with its capital requirements. It even had excess capital. The December 2006 capital ratio of 11.6 percent under Basel I increased to 17.5 percent under Basel II. By June 2007, the Basel II capital ratio had risen to 18.2 percent, far above the regulatory minimum capital requirements.

Two months after publishing the above cited report and positive forecasts the mortgage lender collapsed and seven months later was taken into public ownership.

In the following lines I analyze the reasons for the "quite unexpected" run. Northern Rock was the fifth largest mortgage lender in the U.K focused on residentials with an almost eightfold growth of its balance sheet from 1998 to June 2007 (from $£ 17.4$ billion to $£ 113.5$ billion). Northern Rock had four distinct funding sources - retail, nonretail, securitization and covered bonds. Securitisation was the most significant source of funding for Northern Rock. 
Marinova, M.: Can Capital Ratios be the Centre of Banking Regulation - A Case Study.

Flows of new funding and closing balances were disclosed as follows:

Tab. 2: Northern Rock's funding

\begin{tabular}{|c|c|c|c|c|}
\hline £ millions & Retail & Non-retail & $\begin{array}{c}\text { Securitiza } \\
\text {-tion }\end{array}$ & $\begin{array}{c}\text { Covered } \\
\text { Bonds }\end{array}$ \\
\hline \multicolumn{5}{|l|}{$20071^{\text {st }}$ Half } \\
\hline Net flow & 1734 & 2509 & 5632 & 2194 \\
\hline Closing Balances & 24350 & 26710 & 45698 & 8105 \\
\hline \multicolumn{5}{|l|}{2006 Full Year } \\
\hline Net flow & 2527 & 2876 & 10628 & 2733 \\
\hline Closing Balances & 22631 & 24240 & 40226 & 6202 \\
\hline \multicolumn{5}{|l|}{$20062^{\text {nd }}$ Half } \\
\hline Net flow & 861 & 5205 & 4794 & 1351 \\
\hline Closing Balances & 22631 & 24240 & 40226 & 6202 \\
\hline \multicolumn{5}{|l|}{$20061^{\text {st }}$ Half } \\
\hline Net flow & 1666 & -2329 & 5834 & 1382 \\
\hline Closing Balances & 21773 & 19570 & 36334 & 4965 \\
\hline
\end{tabular}

Source: own presentations based on Northern Rock 2007, 2009

At 31 December 2007, capital deductions in respect of securitized assets amounted to $£ 537.7$ million and were made equally against Tier 1 and Tier 2 capital resources. Regulatory core Tier 1 capital fell to minus $£ 17.1$ million at 31 December 2008 (31 December 2007 - 1316.4 million) and total tier 1 after deductions reduced to minus $£ 110.4$ million (31 December 2007 - 1594.0 million). As a result, the Tier 1 ratio at 31 December 2008 was 0.4\% (31 December $2007-7.7 \%$ ) and the total capital ratio was $10.8 \%$ (31 December $2007-14.7 \%$ ).

Tab. 3: Nothern Rock's Funding - capital ratios

\begin{tabular}{|l|r|r|}
\cline { 2 - 3 } \multicolumn{1}{c|}{} & $\mathbf{2 0 0 8}$ & \multicolumn{1}{c|}{$\mathbf{2 0 0 7}$} \\
\hline Core capital ratio (Tier 1) & $-0.4 \%$ & $7.7 \%$ \\
\hline Capital /solvency ratio & $10.8 \%$ & $14.7 \%$ \\
\hline
\end{tabular}

Source: own presentations based on Northern Rock 2007, 2009 
On 23 February 2009, the Company announced that it had concluded the strategic review of its business plan, in close consultation with the Government. The restructuring through a State aid of $£ 3$ billion was envisaged.

\section{Resuming remark}

The insights from the annual reports and the presented data are:

- Despite long period of regulatory capital ratios far above the regulatory required minimum, Northern Rock collapsed;

- The large securitization and resecuritization exposures did not draw the attention of the Bank's management prior to the financial turmoil;

- Only due to the public ownership Northern Rock survived.

\subsection{Lehman Brothers}

Lehman, one of the largest banks in the world, the fourth-largest bank in the U.S. and once the biggest U.S. underwriter of mortgage bonds lost ca. 75 percent of its market value in 2008. However, on May 31, 2008 Lehman's Capital was as follows:

\section{Tab. 4: Lehman's Capital - capital ratios}

\begin{tabular}{|l|r|}
\cline { 2 - 2 } \multicolumn{1}{c|}{} & May 31, 2008 \\
\hline Core capital ratio (Tier 1) & $10.7 \%$ \\
\hline Capital /solvency ratio & $16.1 \%$ \\
\hline
\end{tabular}

Source: Lehman Brothers (2008a, 2008b)

So obviously, via the regulatory capital ratio no indication of the coming run has been captured. Again, the troubles came from securitization notes.

During 2007, Lehman largely invested in residential mortgages, residential mortgage-backed securities (RMBS), and Commercial Real Estate (CRE) loans (see graph below). 
Marinova, M.: Can Capital Ratios be the Centre of Banking Regulation - A Case Study.

Fig. 4: Lehman's exposure to problematic investments

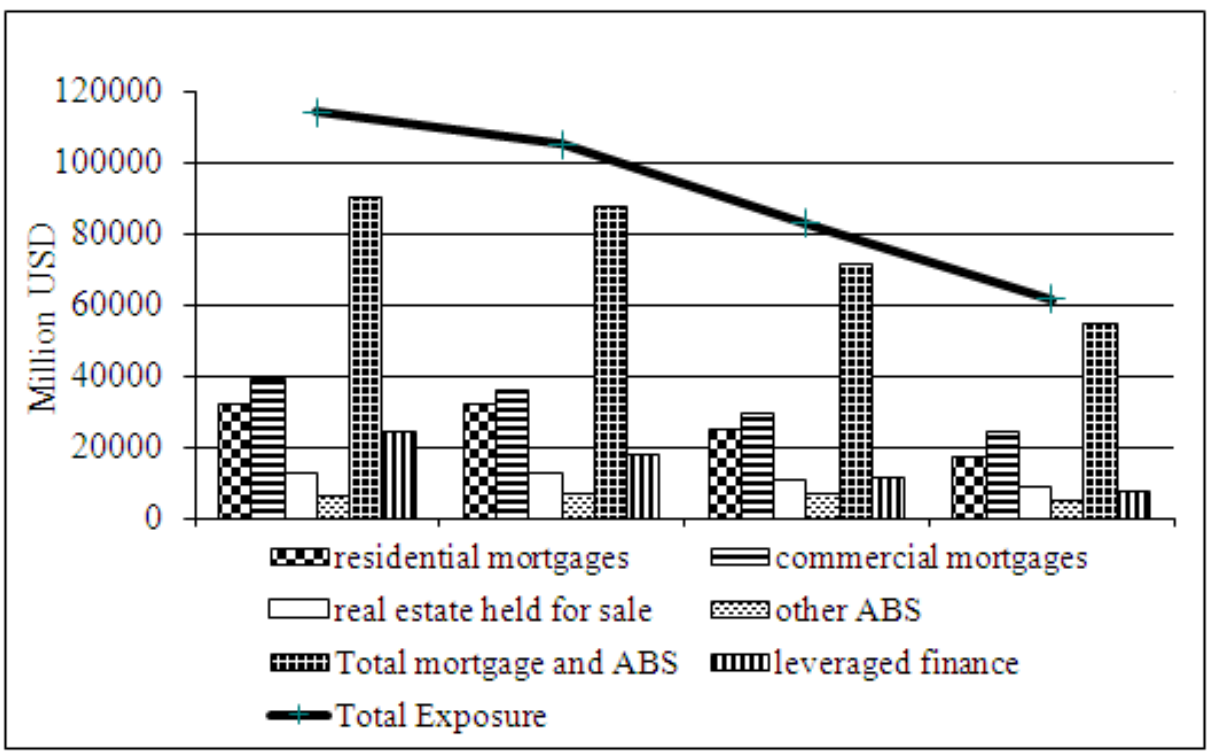

Source: own presentations based on Lehman Brothers (2008a, 2008b)

What had to follow as an inevitable consequence of the turmoil started mid-2007, were the write-downs on these problematic investments.

\section{Resuming remark}

The insights from the annual reports and the presented data are:

- Despite long period of regulatory capital ratios far above the regulatory required minimum, Lehman Brothers collapsed;

- The large securitization and resecuritization exposures did not draw the attention of the Bank's management prior to the financial turmoil.

\subsection{Merrill Lynch}

As presented below the capital ratio situation with Merrill Lynch was more than optimistic measured by the regulatory capital ratios. 
Fig. 5: Capital ratios Merrill Lynch

Capital ratios in percent

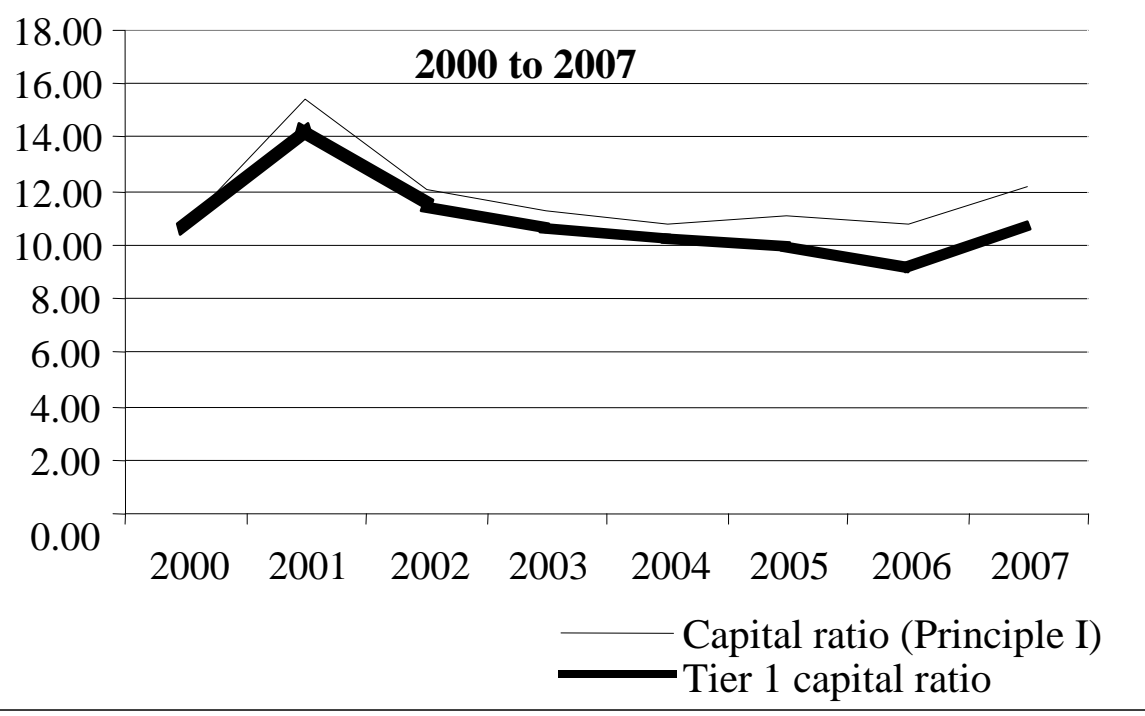

Source: own presentations based on Merrill Lynch (2004, 2005, 2006, 2008)

However, Merrill Lynch was also strongly hit by the recent financial crisis. In July 2008 the bank announced a series of initiatives for enhancing its capital position, among others the sale of $\$ 11.1$ billion U.S. super senior ABS CDO securities which represented a substantial majority of Merrill Lynch's CDO positions. The bank had to book a write-down of a $\$ 4.4$ billion loss associated with the sale of the CDOs. Until the end of 2007 Merrill Lynch incurred additional material losses due to write-downs in the value of financial instruments. According to Merrill Lynch's Annual Report 2007 (pp. 34-38), the recorded significant net write-downs in 2007 were primarily related to U.S. ABS CDOs, sub-prime residential mortgages, and credit valuation adjustments related to hedging transactions with financial guarantors (mainly through credit derivatives) on U.S. ABS CDOs. 
Marinova, M.: Can Capital Ratios be the Centre of Banking Regulation - A Case Study.

Fig. 6: Sub-prime Residential Mortgage-related net exposures and losses per Dec. 28, 2007

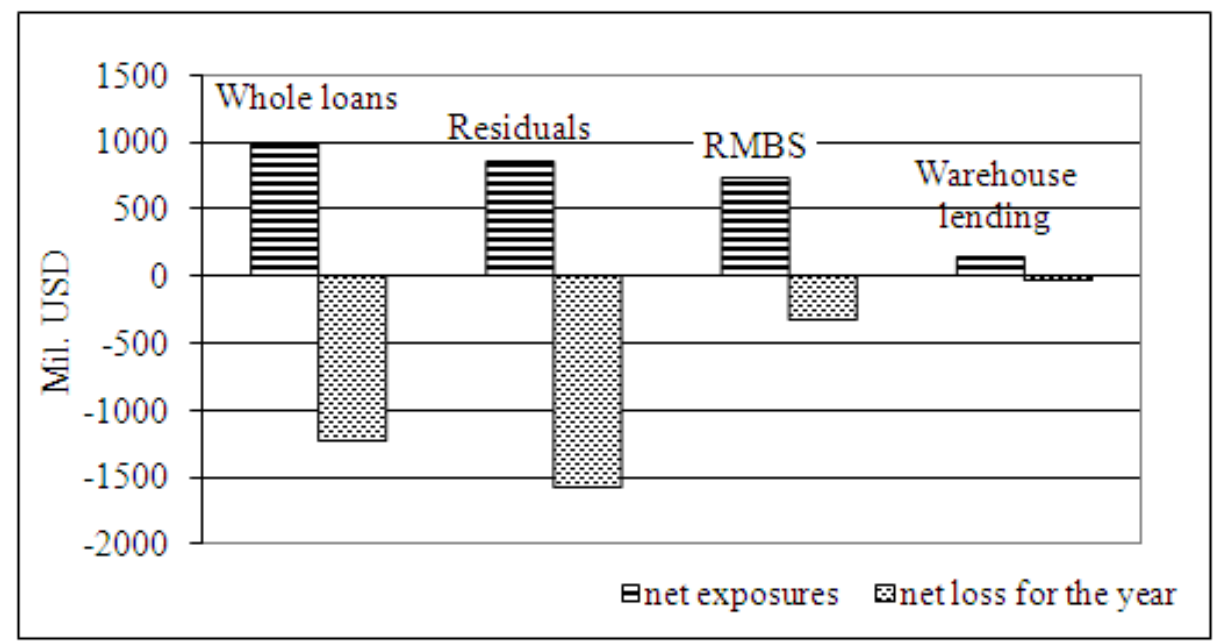

Source: own presentations based on Merrill Lynch (2004, 2005, 2006, 2008)

In addition, Merrill Lynch had exposure to various resecuritization notes - U.S. ABS CDOs on sub-prime residential mortgages.

Fig. 7: Problematic net exposures and losses per Dec. 28, 2007

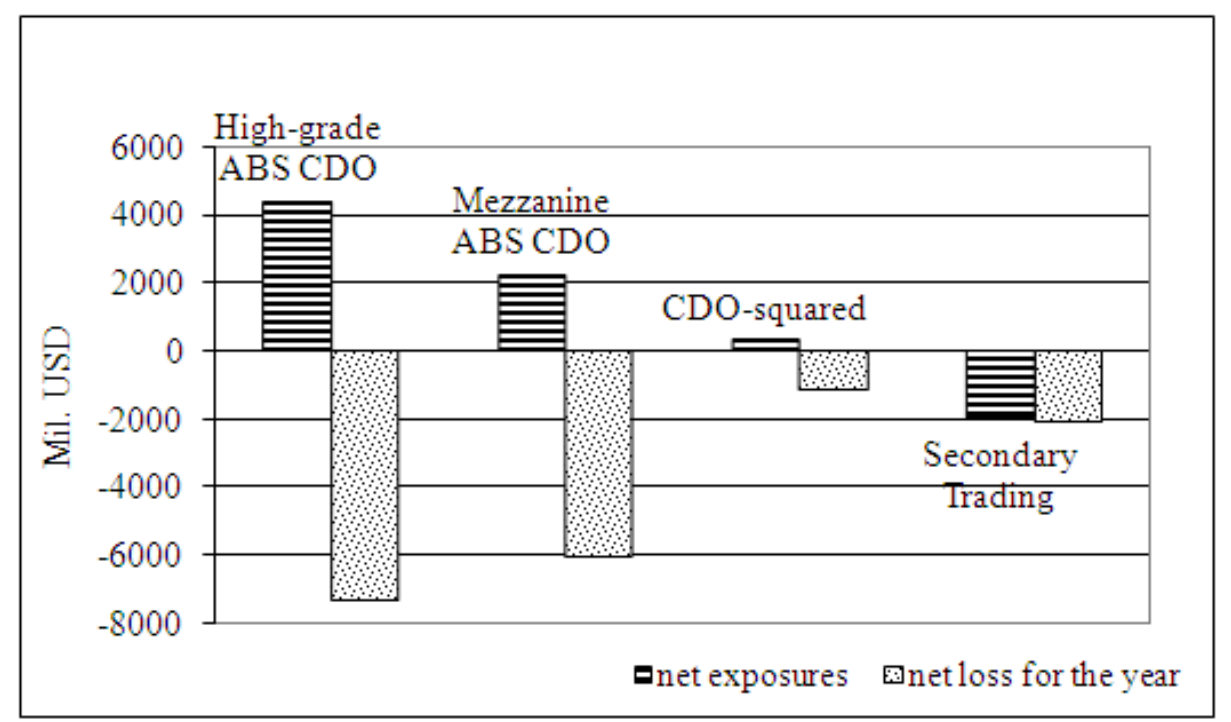

Source: own presentations based on Merrill Lynch (2004, 2005, 2006, 2008) 


\section{Resuming remark}

The insights:

- Despite long period of regulatory capital ratios far above the regulatory required minimum, Merrill Lynch collapsed;

- The large securitization and resecuritization exposures did not draw the attention of the Bank's management prior to the financial turmoil.

\section{Conclusion of the case studies}

The main objective of banking industry - to efficiently allocate capital to borrowers and businesses - was misapplied. Instead capital was distributed to anyone who wanted it.

It is obviously time to ask if the developments in current banking regulation and supervision such as the implementation of the Basel Accords based on the concept of Risk Weighted Assets with Capital Ratios being the center of banking regulation, are the right way of insuring financial stability.

The core question is: Are the capital ratios calculated as a relation between risk-weighted assets and bank's equity the right way to supervise banks?

The concept of Capital Ratios as the center of banking regulation obviously failed, both on an individual bank's level, as well as with a system perspective regarding the cross-banking solvency stability.

This failure requires a deeper insight and more thorough analysis.

In fact, the capital ratios calculated up to date were mostly based on the Basel I Accord.

In the U.S. the implementation of Basel II was planned to start 2009 and only for certain banks. Generally, the scope and timeline for the implementation of Basel II in the U.S. strongly differentiates from the implementation in the rest of the world and is up to now still uncertain. It was proposed that only the largest U.S.-based banks be required to implement Basel II, with other banks being allowed to opt-in with 
Marinova, M.: Can Capital Ratios be the Centre of Banking Regulation - A Case Study.

supervisory approval. The U.S. began with the implementation in 2009, at least two years after Basel II implementation in most of the rest of the world.

In Europe, and more specifically as presented in the above examples in Germany (IKB, Sachsen LB) and Great Britain (Northern Rock), although the Basel II implementation had been already accomplished up to 2009, most of the explanatory data and ratios I referred to in the above examples were still based on Basel I, since the compulsory application in Europe started 2007 - the time when the crisis had already began.

Even if Basel II had been implemented before the financial crisis started mid-2007, it would not have captured the complex risks hidden in securitization and resecuritization exposures and not been able to prevent the financial crisis (as stated by different proponents of the Framework).

First, the available external ratings for securitization and resecuritization exposures were - as long commonly acknowledged wrong. Second, Basel II was by its origin not meant to adequately capture the risk of complex structured finance products with double leverage such as resecuritizations. Third, it is nowadays also commonly acknowledged that Basel II was not able to capture systemic and extreme risks which were the actual risks and some of the causes for the recent financial crisis.

However, numerous early warning indicators at least of a systemic risk could have been identified by the national regulatory bodies, such as the German Banking Regulator BaFin and the Deutsche Bundesbank, or the British Financial Services Authority (FSA).

In particular, the national banking supervisors and regulators receive the complete sets of annual reports from all operating banks as well as audit reports and further documentation regarding the full operating activity of banks. They not only have access to detailed data on banking operations but are also authorized to audit it and interfere in order to counteract undesirable development in the banking and financial services sector. 
For example, Bundesbank and BaFin are jointly responsible for banking supervision in Germany. This is regulated in the German Banking Law (Kreditwesengesetz, KWG). Bundesbank is involved in almost all spheres of Banking Supervision. It is responsible for the comprehensive assessment of all delivered annual reports, audit reports and other regulatory relevant issues. As opposed to the Bundesbank, BaFin is responsible for regulatory authorization issues, such as regulatory approvals, supervision and closing of individual financial institutions.

The Deutsche Bundesbank and BaFin in theory communicate to each other any observations and findings which are necessary for the performance of their respective functions. The cooperation and communications include the communication of personal data. The BaFin and the Deutsche Bundesbank are authorised to automatically access one another's database maintained for the purpose of performing their functions.

I argue that early warning indicators of systemic risk in the financial sector and signs of the coming turmoil were irresponsibly ignored at the time they were perceived.

Analogous regulations apply to the National Regulators and Supervisory Authorities in the rest of the developed countries.

A comprehensive analysis of the data available at BaFin and Bundesbank, which is partially derived from the officially disclosed information by banks and partially from reports available only to regulator and supervision bodies, would have provided a reasonable systemic overview of potential risks at least in the national banking sector.

Such an assessment of the bank sector data should be one of the main tasks of regulator and supervision bodies like BaFin and Bundesbank for the future. For example, numerous credit relations, such as cross-banks loans, credit guarantees, among others credit derivatives, and credit exposures via liquidity commitments as well as investments in complex structured finance products were disclosed long before the sub-prime crisis. 
Only one grotesque example presents Sachsen LB. According to the Annual Report 2005 of Sachsen LB (s. page 24) the wholly owned subsidiary of Sachsen LB - Sachsen LB Europe plc (SLBE), which holds a full banking license - was in 2005 already one of the biggest Asset Backed Securities-Investors in Europe.

Some of the questions to ask are:

- Where was the German Regulator BaFin (or the Bundesbank) when Sachsen LB failed? Were they not in possession of a magnitude of data on the banking activities of Sachsen LB, and were they not obliged to react long before the financial crisis in order to prevent the failure of Sachsen LB?

- Was it adequate for a German Landesbank to be an investor in ABS at all?

- Why did the German supervisor allow a Landesbank affiliate to be one of the largest ABS-investors in Europe? It can never be in line with the concept of Landesbanken

\section{Does banking regulation still have a chance?}

\subsection{The future of banking is unclear}

It is surely premature to ask what the future of banking regulation looks like simply because the future of banking is currently unclear.

The future will be certainly different to different types of banks. What significantly changed for the bigger internationally active banks after the crisis is the government interference in their structures thanks to whom these banks received a chance to survive.

The capital injections and guarantees provided by governments signalled governments' readiness to support and stabilise their banks. However, as a result governments are meanwhile practically incorporated in banking. In reality, many banks nowadays still exist thanks to the governments that supported them and thus helped to escape their bailouts.

The future of the banks which were largely supported by their governments is on the one hand secure. On the other hand, the strong government involvement can itself be an uncertainty factor for a bank's 
future. The failures have shown that management of balance-sheets, banking operations, risk management techniques and even the payment schemes to managers must be changed.

\subsection{Regulation for systemic risk}

Systemic risk as a threat to financial stability was pre-crisis perceived to be typical for banks. Today, with the post-crisis knowledge and insights, it is widely recognised that the process of securitization has changed that perception.

The substantial under-pricing of the credit risk in securitizations and the wrong notion that a large portion of the credit risk in sub-prime securities was idiosyncratic and hence diversifiable generated an excessive demand for sub-prime issuance.

Post-crisis, it is clear that the greater portion of this risk was systemic. Indeed, the credit rating agencies (CRA) failed to adequately predict performance because of their wrong empirical valuation models. However, some other factors were not adequately addressed as well.

Leverage is clearly a factor for generating systemic risk in an economic sector. Prudent leverage is a valuable financial tool but excess leverage is a threat for the financial system and any business. Indeed, overleveraging i.e. doing business with high ratio of borrowing in relation to equity, was a key factor for converting the initial sub-prime turmoil in 2007 into a financial bubble in 2008. The strongest leveraged financial intermediaries in the current financial system are broker-dealers and hedge funds.

Another danger for the financial system is the successively built shadow financial system. The key components of the shadow financial system are unregulated financial instruments such as off-balance-sheet entities and non-bank institutions such as hedge funds, asset managers and private equity funds. Adequate monitoring of counterparty risk, adequate risk management practices and reporting standards completely failed for these market participants.

This shadow financial system is a source of significant systemic risk and at the same time mostly outside the scope of the financial 
Marinova, M.: Can Capital Ratios be the Centre of Banking Regulation - A Case Study.

regulation. In addition, exactly these non-bank institutions brought a great leverage excess.

Special attention should be paid to certain non-bank institutions with extremely high leverage strategies meanwhile also invested in securitizations - the private equity companies. Since most of them are not subject to disclosure requirements large securitization tranches are supposingly hidden on their books. This is not a thread for the single private equity companies but is still a systemic thread to the economy where these companies expand since large hidden risks may inflate the next financial bubble.

Standard setter and supervisors should define the regulatory treatment at non-bank institutions. Comprehensive risk management practices and risk reporting should be required not only for large financial institutions, but also for entities that so far have managed to stay outside the reporting obligations set by supervisors, such as hedge funds, or offshore bodies.

Sector-specific information on the exposure of the banking sector to particular risks is another issue of transparency. A single bank may be strongly exposed to some sector specific risks, such as automobile or mortgage financing, without endangering financial stability of the whole economy if these risks materialize. However, if the banking sector is systematically exposed, these risks may destabilize the financial system as a whole. Thus, sector-specific information can be a useful warning signal for banks ready to enter those risks. Central banks and supervisors should be able to follow the allocation of risk exposures in financial markets.

Meanwhile it is almost impossible for regulators to capture the real dynamics of capital markets. The lesson to learn is that Systemic Risk must be timely identified and regulated.

Practically, today no regulatory authority monitors if financial institutions or products generate and pose systemic risk to the economy. This issue must be accordingly addresses. Systemic risk should be timely managed by regulators in order to avoid financial crisis such as the disaster of 2007 and 2008.

Otherwise the taxpayer must practically bear the consequences of a systemic turmoil. 


\section{Conclusions - Implications of securitization products for financial stability}

In this section I solely summarize that securitization techniques have largely contributed to inefficiency and destabilizing the financial system.

According to the academic literature on securitization besides its advantage to "save" capital, securitization products were perceived to improve financial stability by dispersing risks among many investors ${ }^{10}$. Duffie argues that if credit risk transfer leads to more efficient use of lender capital, the cost of credit is lowered, presumably leading to general macroeconomic benefits such as greater long-run economic growth.

Such theories are nowadays questionable.

The most significant issue is that individual banks indeed became less risky but generated greater risks to the financial system at the same time.

Lenders transferring significant exposures to a borrower's default have less incentive to monitor the borrower and control his risk-taking.

Thus, securitization divorced risk from controls by isolating the securities from the underlying collateral and allowed for a continued segmentation of the lending process which stretched out the lending process.

This anomaly results in a raise of total amount of credit risk in the financial system and leads to inefficient economic activities by borrowers.

A further argument against the long-run benefits of securitization is the high complexity of credit risk transfer products which complicates their valuation and analysis for investors and rating agencies. Even specialists in securitization notes like CDOs proved to be incompetent in valuation of their risks and default correlations. Default correlations remain the weakest point in credit risk transfer products.

${ }^{10}$ For example according to IMF in "Influence of credit derivatives and structured credit markets on financial stability" or to Duffie (2008). 
Marinova, M.: Can Capital Ratios be the Centre of Banking Regulation - A Case Study.

Fig. 8: Model of a reasonable usage of the current financial regulation

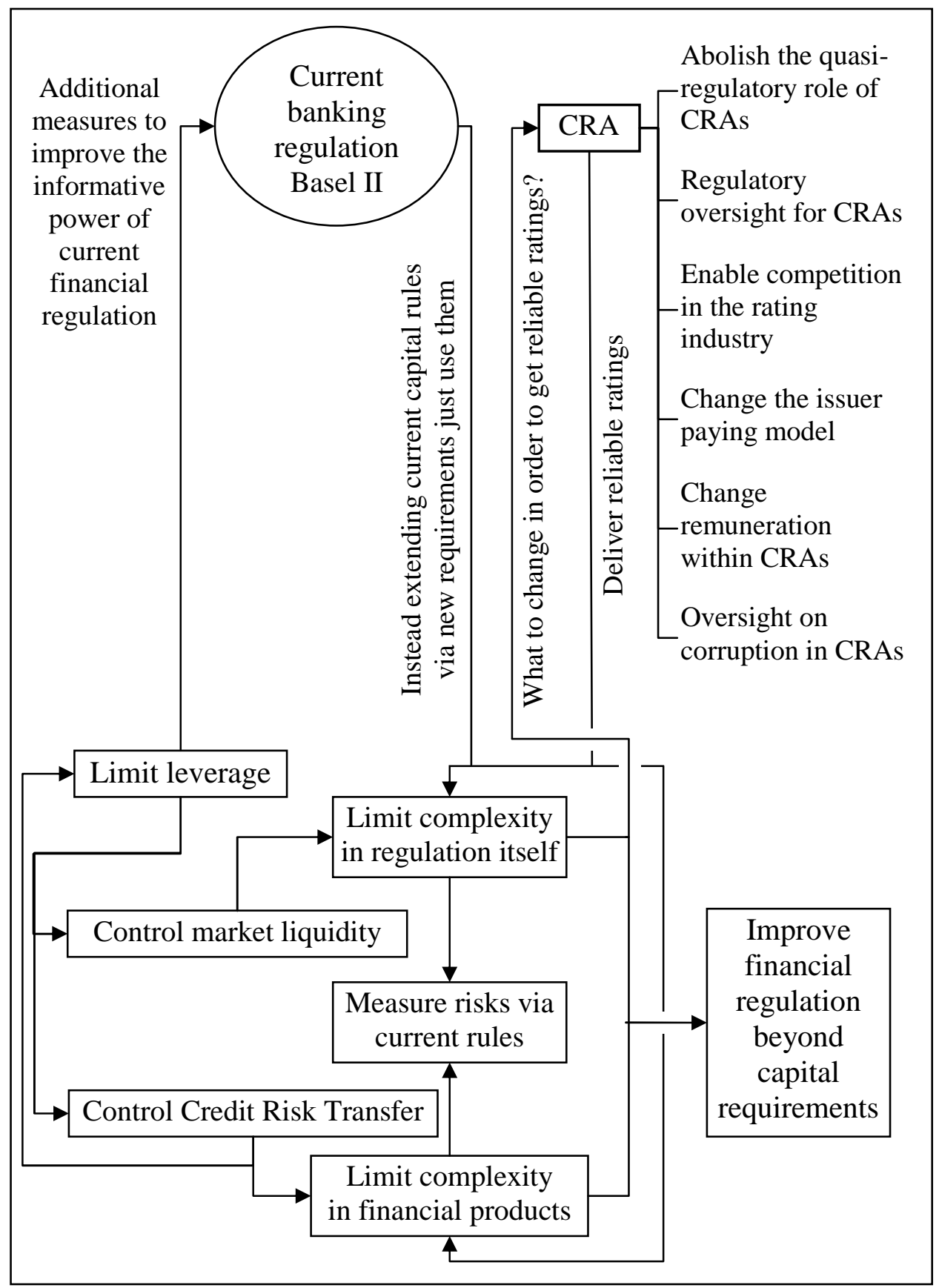

Source: own presentation 
Financial innovation in credit risk transfer led to reduction in the degree to which credit is intermediated by banks in relation to hedge funds and asset managers. This in turn de facto resulted in lax underwriting guidelines and a loss of internal controls on the issuing side. As a result, the long-run macroeconomic growth was even threatened.

With regard to the prime originator of securitization activity - the United States - another shortfall of securitization activity must be defined. Securitization practically increased the general indebtedness of all Americans because of the cheapness of credit.

In the figure 8 I summarize my recommendations and partial solutions for a reasonable usage of the current financial regulation.

\section{References}

[1] Duffie, D. (2008): Innovations in credit risk transfer: implications for financial stability. [on-line], Basel, Bank for International Settlements, Working Papers No 255, c2008, [cit. $12^{\text {th }}$ October, 2009], <http://www.bis.org/publ/work255.htm>.

[2] IKB (2007a): 6-Month Report 2006/07, 1 April - 30 September 2006. [on-line], Düsseldorf, IKB Deutsche Industriebank, c2008, [cit. 12 ${ }^{\text {th }}$ October, 2009],

<http://www.ikb.de/content/en/ir/financial_reports/interim_reports/ IKB_ZB_Q2_2006_07_en.pdf >.

[3] IKB (2007b): IKB Annual report 2006/2007. [on-line], Düsseldorf, IKB Deutsche Industriebank, c2008, [cit. 12 ${ }^{\text {th }}$ October, 2009], $<\mathrm{http}: / /$ www.ikb.de/content/en/ir/financial_reports/annual_report_ 2006_2007/IKB_Konzern_engl_080606_sicher.pdf>.

[4] IKB (2008): IKB Annual report 2007/2008. [on-line], Düsseldorf, IKB Deutsche Industriebank, c2008, [cit. 12 ${ }^{\text {th }}$ October, 2009],

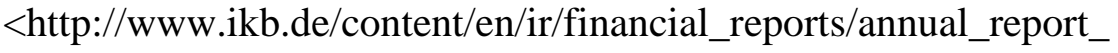
2007_2008/Konzern_englisch_080814_sicher.pdf>.

[5] IKB (2009): 6-Month Report 2008/09, 1 April - 30 September 2008. [on-line], Düsseldorf, IKB Deutsche Industriebank, c2009, [cit. 12 ${ }^{\text {th }}$ October, 2009], <http://www.ikb.de/content/en/ir/financial_reports/interim_reports/ IKB_Halbjahres_englisch15777.pdf>. 
Marinova, M.: Can Capital Ratios be the Centre of Banking Regulation - A Case Study.

[6] Landesbank Sachsen Girozentrale (2006): Konzernabschluss und Jahresabschluss zum 31. Dezember 2006. [on-line], Leipzig, Sachsen LB, c2006, [cit. 12 ${ }^{\text {th }}$ October, 2009], <http://www.sachsenbank.de/imperia/md/content/sb/pdf/finanz/Jah resfinanzbericht_2006.pdf >.

[7] Landesbank Sachsen LB (2005): Sachsen LB Geschäftsbericht 2005. [on-line], Leipzig, Sachsen LB, c2006, [cit. $12^{\text {th }}$ October, 2009], $<$ http://www.sachsenbank.de/imperia/md/content/sb/pdf/finanz/sb_ gebe_2005.pdf $>$.

[8] Landesbank Sachsen LB (2007): Sachsen LB Geschäftsbericht 2006. [on-line], Leipzig, Sachsen LB, c2006, [cit. $12^{\text {th }}$ October, 2009],

<http://www.sachsenbank.de/imperia/md/content/sb/pdf/finanz/sb_ gebe_2006.pdf>.

[9] Landesbank Sachsen LB (2008): Sachsen LB Geschäftsbericht 2007. [on-line], Leipzig, Sachsen LB, c2008, [cit. $12^{\text {th }}$ October, 2009],

<http://www.sachsenbank.de/imperia/md/content/sb/pdf/finanz/SL B_GeBe_2007_D.pdf>.

[10] Landesbank Sachsen LB Europe (2007): Landesbank BadenWürttemberg Annual Report 2006. [on-line], Stuttgart, Landesbank Baden-Württemberg, c2007, [cit. 12 $2^{\text {th }}$ October, 2009], <http://www.lbbw.de/imperia/md/content/lbbwde/ueberuns/gescha eftsbericht/2006/en/2006_SC_89611_GB06_engl_1.pdf>.

[11] Lehman Brothers (2008a): Lehman Brothers Annual Report 2007. New York, Lehman Brothers, 2008.

[12] Lehman Brothers (2008b): Lehman Brothers Interim Reports 2008. New York, Lehman Brothers, 2008.

[13] Merrill Lynch (2004): 2004 Factbook. [on-line], New York, Merrill Lynch, c2006, [cit. $12^{\text {th }}$ October, 2009], <http://www.ml.com/annualmeetingmaterials/2004/ar/pdfs/2004Fa ctbook.pdf $>$.

[14] Merrill Lynch (2005): 2005 Factbook. [on-line], New York, Merrill Lynch, c2006, [cit. $12^{\text {th }}$ October, 2009], $<$ http://www.ml.com/annualmeetingmaterials/2005/ar/pdfs/2005Fa ctbook.pdf\#8>. 
[15] Merrill Lynch (2006): 2006 Factbook. [on-line], New York, Merrill Lynch, c2006, [cit. 12 ${ }^{\text {th }}$ October, 2009], $<$ http://www.ml.com/annualmeetingmaterials/2006/ar/pdfs/2006Fa ctbook.pdf $>$.

[16] Merrill Lynch (2008): Merrill Lynch Annual Report 2007. [online], New York, Merrill Lynch, c2008, [cit. 12 ${ }^{\text {th }}$ October, 2009], <http://www.ml.com/annualmeetingmaterials/2007/ar/>.

[17] Northern Rock (2007): Northern Rock plc Interim results 6 months ended 30 June 2007. [on-line], Newcastle upon Tyne, Northern Rock, c2009, [cit. 12 ${ }^{\text {th }}$ October, 2009], $<$ http://companyinfo.northernrock.co.uk/downloads/stockEx07072 5.pdf $>$.

[18] Northern Rock (2009): Northern Rock plc Annual Report and Accounts 2008. [on-line], Newcastle upon Tyne, Northern Rock, c2009, [cit. 12 ${ }^{\text {th }}$ October, 2009],

<http://companyinfo.northernrock.co.uk/downloads/2008_annual_r eport.pdf $>$. 
Marinova, M.: Can Capital Ratios be the Centre of Banking Regulation - A Case Study.

\section{Can Capital Ratios be the Centre of Banking Regulation - A Case Study}

\section{Milena MARINOVA}

The application, or to be more precise, the misapplication of securitization in the mortgage market had fatal consequences for the financial sector worldwide. More over securitization techniques enabled single banks to reduce their individual risk while at the same time transferred greater risk to the financial system.

Meanwhile a lot was written on the causes for the recent financial crisis. In most cases inadequate ratings provided by the credit rating agencies and different principal agency problems were addressed.

I argue that international and national financial supervisors established an inadequate framework for financial regulation and supervision, and among other failures, even supported credit rating agencies to further establish their businesses. Further on, I argue that early warning indicators of systemic risk in the financial sector and signs of the coming turmoil were irresponsibly ignored at the time they were perceived.

What turned obvious during and after the recent financial turmoil is that capital regulation failed to reach its main goal - ensuring stability of the financial system. In particular, securitization and related credit risk transfer products were adequately treated neither in Basel I nor in Basel II.

With the development of both Basel Accords capital ratios became the center of banking regulation. However, capital ratios are obviously not sufficient as a measure for a systemic financial stability. It is time to ask if the developments in Basel II are the right way of banking regulation and supervision and in particular, if capital ratios can be the centre of banking regulation?

Key words: Mortgage securitization; Financial crisis; Banking regulation; Capital adequacy.

JEL classification: $\quad$ G2, G21, G24, G28. 